DOI: https://doi.org/10.34069/AI/2022.49.01.10

How to Cite:

Chuvakov, O., Balobanova, D., Samadova, S., \& Barbul, P. (2022). Conceptual foundations for the systematization of crimes against the basics of national security of Ukraine and some other countries. Amazonia Investiga, 11(49), 86-92. https://doi.org/10.34069/AI/2022.49.01.10

\title{
Conceptual foundations for the systematization of crimes against the basics of national security of Ukraine and some other countries
}

\section{Концептуальні основи систематизації злочинів проти основ національної безпеки України та деяких інших країн}

Received: December 12, 2021

\begin{abstract}
Crimes against national security (CaNS) are considered the most dangerous encroachment on public relations, aimed at maintaining independence, defense, and the general constitutional order of the state. The lack of proper legal protection of these social relations prevents the stable functioning of the state and its institutions, which is interrelated with the fight against crime. Given this, it is essential to analyze the ground for the systematization of CaNS and a strong theoretical basis for the study. The article aims to analyze the general principles of systematization of CaNS. The object of the study is the diversity of ways of systematization of CaNS in Ukraine, Azerbaijan, and other countries. During the research, such methods were used as a generalization, formal-legal method, method of analysis of normative documents, articles and monographs, comparative-legal method. As a result of the study, the main ways of systematization of CaNS in different countries are examined and main characteristics of systematization are settled.
\end{abstract}

Keywords: crimes against the basics of national security, national security, system of crimes, systematization.
Accepted: January 20, 2022

Written by:

Oleh Chuvakov ${ }^{36}$

https://orcid.org/0000-0001-9983-8943

Daria Balobanova ${ }^{37}$

https://orcid.org/0000-0001-7247-0560

Shakhla Samadova ${ }^{38}$

https://orcid.org/0000-0001-6995-7140

Pavlo Barbul ${ }^{39}$

https://orcid.org/0000-0003-1444-7383

\begin{abstract}
Анотація
Злочини проти національної безпеки (ЗпНБ) вважаються найбільш небезпечним посяганням на суспільні відносини, що мають на меті забезпечити державну безпеку, незалежність, обороноздатність, та загалом конституційний лад держави. Відсутність належної правової охорони вказаних суспільних відносин унеможливлює стабільне функціонування держави та іiі інститутів, що знаходиться у взаємозв'язку із боротьбою зі злочинністю. 3 огляду на це, важливо проаналізувати концептуальні основи систематизації ЗпНБ. Метою роботи $\epsilon$ аналіз та дослідження загальних засад та принципів систематизації ЗпНБ. Об'єктом дослідження є різноманітність підходів до систематизації ЗпНБ в Україні, Азербайджані та інших державах. Методологія статті включає: метод узагальнення, формально-юридичний метод, метод аналізу та порівняльно-правовий метод. $\mathrm{B}$ результаті проведеного дослідження проаналізовано основні підходи до систематизації злочинів проти національної безпеки у різних країнах, встановлені головні маркери систематизації.
\end{abstract}

Ключові слова: злочини проти основ національної безпеки, національна безпека, система злочинів, систематизація.

\footnotetext{
${ }^{36}$ Doctor of Legal Sciences, Head of the Department of Criminal Law, Criminal Procedure and Criminology, Odesa I.I. Mechnikov National University, Ukraine.

${ }^{37}$ Doctor of Legal Sciences, Associate Professor, Professor of the Department of Criminal Law and Criminology, Lviv State University of Internal Affairs, Ukraine.

${ }^{38}$ Doctor of Legal Sciences, Professor, Head of the Department of Criminal Law and Criminology, Baku State University. Baku, Azerbaijan Republic.

${ }^{39} \mathrm{Ph} . \mathrm{D}$., advocate, Ukraine.
} 


\section{Introduction}

Crimes against national security are one of the most socially dangerous crimes, as they encroach on the very existence of the state. In the current conditions of geopolitical instability and the attempts of some countries to redraw the internationally recognized borders by any means, the issue of adequate application of criminal responsibility to those who undermine national security becomes especially relevant. In particular, it is a question of proper systematization of such crimes. The research is devoted to this problem.

The authors of the article tried to analyze the very definition of crimes against national security, taking into account current challenges, distinguished relevant crimes from other socially dangerous acts and thoroughly investigated the problem of their systematization. At the same time, the study is based on the experience of Ukraine, Azerbaijan and a number of other countries for which the stated issues are relevant.

Ukrainian legislation defines national interests as vital material, intellectual and spiritual values of the Ukrainian people as the bearer of sovereignty and the only source of power in Ukraine, determining the needs of society and the state, the implementation of which guarantees state sovereignty of Ukraine and its progressive development.

Therefore, given the systemic and long-term nature of the threats to these interests, there is every reason to believe that national security should become a national idea for each state. Undoubtedly, to ensure national security, it is important to establish an effective mechanism for combating CaNS (hereinafter - CaNS). In general, national security is a state of protection of vital interests of man and citizen, society and the state, which ensures sustainable development of society, timely detection, prevention, and neutralization of real and potential threats to national interests, namely: existing and potential phenomena and factors pose a danger to these interests. Improving the efficiency of the public administration system is carried out by reforming the institutions of national security, increasing the level of professionalism and responsibility of officials in all its parts, which, obviously, is impossible without adequate intellectual and personnel support.

Following Article 1 of the Law 2469-VIII (2018), national security is the protection of vital interests of man and citizen, society and the state, which ensures sustainable development of society, timely detection, prevention, and neutralization of real and potential threats to national interests in the areas of law enforcement, anti-corruption, border and defense, migration policy, health, education and science, science, technology and innovation policy, cultural development, freedom of speech and information security, social policy and pensions, housingeconomy, financial services market, protection of property rights, stock markets and securities circulation, fiscal and customs policy, trade and business, banking services, investment policy, auditing, monetary and monetary policy, information protection licensing, industry and agriculture, transport and communications, information technology, energy and energy saving, functioning of natural monopolies, subsoil use, land and water resources, minerals, protection of ecology and environment and other areas of public administration in the event of negative tendencies to create potential or real threats to national interests; national interests are vital material, intellectual and spiritual values of the Ukrainian people as the bearer of sovereignty and the only source of power in Ukraine, determining the needs of society and the state, the implementation of which guarantees the state sovereignty of Ukraine and its progressive development; threats to national security existing and potentially possible phenomena and factors that endanger the vital national interests of Ukraine.

Today, ensuring national security is in the spotlight among all countries of the world. Addressing issues related to countering national security is the cornerstone of their domestic and foreign policies, the development and practical implementation of which are directed to significant intellectual and human resources of the nation. This state of affairs is due to several factors that generate a set of interrelated tasks assigned to national systems and international security structures.

\section{Theoretical Framework or Literature Review}

The following scientists studied the theme of the article in their researches: Anashkin (1964), Afanasenko and Stoykov (2015), Baranin (2019), Vecherova (2015), Gorbunova (2016), Ryabchuk (2007), Samedova (2017), and Shatanska (2017).

Therefore, Anashkin (1964) analyzed the peculiarities of the crime of "treason" and aimed 
to determine the place of this crime in the system of CaNS.

Another scholars Afanasenko and Stoykov (2015) studied CaNS that encroach on political relations. The authors define crimes against the foundations of national security as provided by the Criminal Code (hereinafter refer to CC) as socially dangerous acts that cause significant damage to the security of the state and society in various spheres and related vital interests or threaten to cause such damage, and for the vast majority of which is typical, the goal is to weaken the state. Morevoer, Baranin (2019) analyzed and generalized the general theoretical principles of the systematization of crimes. Furthermore, Gorbunova (2016), studied in detail the systematization of CaNS on the example of prosecution for espionage and treason in Austria and Liechtenstein. Besides, Ryabchuk (2007) conducted a criminal law and criminological study of treason and espionage. Additionally, Samedova (2017) addressed the problematic aspects of the differentiation of criminal responsibility.

Further, Chuvakov (2017) analyzed how to counter CaNS. The author considered the genesis of the conceptual apparatus of such crimes, the process of establishing the nature, features, and types of analyzed crimes in the modern period. The author analyzes the problematic issues of differentiation of CaNS of Ukraine into certain types and the establishment of their specific objects, examines in detail both the main and additional features of the objective and subjective side of the analyzed crimes; their significance in the qualification of such crimes is determined and the legal analysis of CaNS of Ukraine is carried out taking into account the provisions of their improvement proposed by the author. Besides, Shatanska (2017) focused on the study of CaNS and their qualifiers.

Additionally, Vecherova (2015) concludes that the axiom "homogeneity of social relations" is inviolable, which requires a change of location of some articles of the criminal law. In addition, the researcher notes the need to rethink the benefits protected by law and the need to distinguish: crimes against the person, crimes against society, and crimes against the state.

David Pion-Berlin (1989) in his article «Latin American National Security Doctrines: Hard and Softline Themes» analyzes different versions of the Doctrine of National Security, which was spread in different Latin American countries in the 60-70s of the twentieth century.
Gabriel Marcella (2013) in the article «The Transformation of Security In Latin America: A Cause for Common Action» analyzes the concepts of national security that emerged in Latin America after the end of the Cold War. Mostly, these are the concepts of multidimensional security and security of the individual and society, in contrast to the classical understanding of national security, created by an external threat to the state.

Mamedov R.Y.O. (2016) in his article «Legal offenses against peace, human security, public safety under the criminal legislation of the Azerbaijan Republic» analyzes the legal offenses against the peace and security of mankind, public safety under the criminal legislation of the Azerbaijan Republic. In addition, the author touches on issues of cooperation between states in the fight against crimes against national security, in particular, the interaction of the CIS countries.

Aliyev A.I., Rzayeva G.A., \& Ibrahimova A.N. (2020) in their article «Information Security: Legal Regulations in Azerbaijan and Abroad» analyze information security issues in the world and in Azerbaijan, in particular. The article compares laws and regulations of Azerbaijan and other countries in the cybersecurity policy between them. The article reveals the features of the organizational and legal regulation of the information security system as an integral part of state security.

The above analysis of the literature confirms the considerable attention of scholars and lawmakers to the issue of systematization of CaNS (both external and internal). However, a large number of studies do not diminish the significance of the research topic and require further research on the basic principles of creating a system of crimes in the field of state security in the challenges of modern society.

\section{Methodology}

The following methods were used in the study: generalization, formal-legal method, method of analysis of normative documents, articles and monographs, and comparative-legal method.

Thanks to the method of generalization, it became possible to draw conclusions about the variety of systems of CaNS, as well as the basis that became the basis for the formation of an approach to systematization. In general, the method of generalization is aimed at fixing the general features and properties of a certain class 


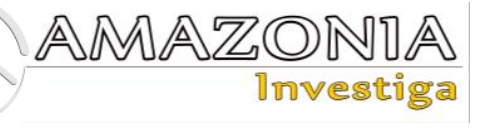

of objects and making the transition from single to general, from less general to more general. including the systematization of CaNS, highlighting political CaNS, global crimes, etc.

Such a method as a formal-legal method was utilized to justify the need for continuous improvement of the current systematizations of crimes that threaten national security. In the study, this method allows us to trace the relationship between internal content and external expression of state and legal phenomena and institutions using legal techniques, the formal-legal method allowed us to formulate the main definitions of crime, national security, defense, constitutional order, etc. Moreover, this method contributed to the transformation of certain provisions and assumptions of the research question in the construction, concept, and typology, as well as helped to provide a definition of some controversial concepts.

The comparative-legal method helped to reveal the way of the systematization of crimes and approaches in foreign countries. As far as we know, the comparative-legal method helps to specify the number of general and special methods in the study of their subject, as it is due to its properties and patterns, and the basis for comparative-legal analysis is comparison, i.e. comparison of anything to establish similar or distinctive features, identify the same features or differences. Moreover, when using the comparative-legal method, such techniques as collecting and studying facts, analysis, abstraction, comparison, evaluation, and generalization were used. That is, the use of the comparative-legal method was carried out comprehensively. Thus, this method was considered the method of systematization on the example of Ukraine, Russia, and Azerbaijan. States interpret the need for systematization differently, but they all understand that logically constructed systematization plays an important role in the theory of criminal law.

\section{Results and Discussion}

\section{General provisions on the systematization of CaNS}

In chronological perspective, the concept of "national security" has deep roots. Analysis of history shows that the need for security is one of the main motives for people and communities. The problem of security and its provision at the level of developing a categorical apparatus of social science for many centuries has been the focus of philosophers, historians, political scientists, and jurists. Already in antiquity and the Middle Ages, there is a certain concept that security is a complex socio-political phenomenon that is a priority goal and leading function of the state, which is achieved by special measures that are directly related to the existence and development of society and states.

In general, the main components of modern security interpretation are identified: external and internal threats; state security: defense and defense against external enemies; state security the security of a special organization of public authority, the role of the state as the main subject of security, as well as the security of society and citizens. At the same time, especially in the Middle Ages, the security of the government was guaranteed by the existence of law and special state bodies, whose action was aimed at both threats outside the object of protection (authorities) and threats that arise in itself (own safety).

Simultaneously, when considering issues of national security in research and lawmaking, different terms are used: "security", "security of the individual, society, and state", "state security", "security of the country", etc.

The notion of "national security" reflects the connection of security with the nation, i.e. with a certain territorial and state community based on stable socio-political, economic, cultural, and other ties. A nation can include many nationalities, which is an ethnic community of people with their own traditions, rights, and culture. In this regard, national security, which characterizes the state of the nation as a holistic system, including social relations, public consciousness, institutions of society, and their activities that promote or hinder the realization of national interests in a particular historical context. Based on the central premises of the concept of national interests, the notion of "state security" can be defined as a state (property) of the state, which created the conditions for the existence of the constitutional system, sovereignty, and territorial integrity of the state, including, for example, Ukraine.

Problematic issues of national security can be rethought through a broad vision, i.e. through the concept of modern criminal policy. The primary task of the criminal policy of Ukraine is aimed at setting problems, indicating the grounds and directions, developing forms and methods of activity, deployment of forces and means, providing information, monitoring activities, and leadership. These constituent elements are 
included in the criminal policy as its leading characteristics. This list can be achieved through a coordinated systematization of crimes against national security. Hence, to effectively organize the fight against crime, it is necessary to determine acts that are legally appropriate to recognize as crimes and to define the penalties that may be imposed by the court on behalf of the state for committing such acts. Such definitions are made based on the provisions of criminal law and are expressed in the criminal law of different states.

Thus, depending on the sources of threats to the foundations of national security of Ukraine, conditionally, all crimes under consideration can be divided into two types: 1) crimes that encroach on external security (treason) (Article 111 of the $\mathrm{CC}$ ) and espionage $\mathrm{CC}$ ) and 2) crimes that encroach on internal and economic security (Articles 109, 110, 112 and 113 of the CC of Ukraine).

In connection with these provisions, there is a need to establish the main criteria that determine the existence of such types of crimes and, accordingly, specific objects that contribute to the division of such crimes into appropriate types and in general, their systematization.

Establishing such criteria may make it possible to distinguish more clearly crimes against external security from, for example, crimes against internal security, and other types of crimes.

\section{International experience in systematizing CaNS}

Firstly, it will be logically to consider the conceptual basis for the systematization of CaNS on the example of different countries.

For example, criminal liability for crimes against state power is provided in Section XI of the current CC of the Republic of Azerbaijan (Law 302-IIQD, 1999), which consists of four sections $(31,32,33$, and 34), including articles 274 to 326 inclusive. In total, in Section XI of the 1999 CC. As of December 15, 2021, responsibility is established for 146 corpus delicti, most of which are crimes that do not pose a great public danger and less serious crimes $(75.3 \%)$. It should be noted that since the years of the CC of the Republic of Azerbaijan in 1999, the normative volume of the analyzed section has changed significantly. It was supplemented by 14 new articles (42 corpus delicti), i.e. in total, $28.8 \%$ of crimes against state power were introduced into the Special Part of the CC in 1999 after its entry into force. The main feature of the systematization of crimes against state power in the $1999 \mathrm{CC}$ is that according to the constitutional provision on the priority of protection of human rights and freedoms for the first time in the history of criminal law this group of crimes in the Special Part is not only crimes against military service. However, it should be remarked that the transfer of a group of crimes against state power from the first (CC of 1922, 1927, and 1960) to the fifth place in the hierarchy of the Special Part of the CC of the Republic of Azerbaijan in 1999. means that the actions included in Section XI have become less dangerous. The location of crimes against state power in the system of the Special Part indicates only that the interests of the person protected by criminal law take precedence over the interests of the state, and this is in line with international humanistic and democratic principles of statebuilding. All chapters included in Chapter XI of the 1999 CC, to some extent separated in separate sections, predominate in all three previous $\mathrm{CC}$ of the Azerbaijan Republic of the Soviet period (1922, 1927, and 1960). Thus, the head of state crimes (counter-revolutionary crimes) opened special parts of all three CCs of the Soviet period, and they were systematized in separate chapters of crimes against government and official (official) crimes. Only crimes against justice were first separated only in the 1960 CC. CC of the Republic of Azerbaijan 1999, for the first time, united these groups of crimes in one section under the general title "Crimes against state power". At the same time, the list and content of the norms of these types of crimes have undergone significant changes due to the qualitatively new Constitution of the Republic of Azerbaijan in 1995, which proclaims human rights and freedoms, and the principle of independence and equality of three branches of government (executive, legislative and judicial) is the basis of a democratic state governed by the rule of law (Samandarova, 2021). The generic object of crimes against the structure of state power of Azerbaijan is public relations, which ensure state security, i.e. the state of protection and normal functioning of state power in general, as well as its institutions and bodies. The most dangerous of the crimes that make up this section are encroachments on the constitutional order and security of the state, as they affect the foundations of the social, political, and state system of the Republic of Azerbaijan, sovereignty, external and internal security. In the science of criminal law of Azerbaijan, there are many classifications of crimes that encroach based on constitutional security and defense capabilities of the state, and the most successful proposal is to classify crimes against the 


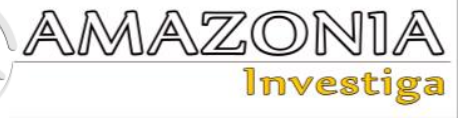

constitutional order and security of the state into the following types:

- crimes that encroach on the external security of the Republic of Azerbaijan (Articles 274, 275, 276);

- crimes that encroach on the internal security (political system) of the Republic of Azerbaijan (Articles 277, 278, 279, 280, 281);

- crimes related to extremist activities (Articles 283, 283-1);

- encroachment on the economic security and defense capabilities of the Republic of Azerbaijan (Article 282);

- crimes that encroach on the security of national secrets (Articles 284, 284-1, 285) (Samedova, 2017).

In Ukraine, articles on liability for CaNS of Ukraine are presented in the first section of the Special Part. The generic object of the crimes provided for in this section is public relations for the protection of the foundations of the national security of Ukraine: its constitutional order, sovereignty, territorial integrity, defense. In other words, the generic object of these crimes is public relations, which ensures the very existence of Ukraine as a sovereign, independent, democratic, social, and legal state (Law 2341-III, 2001). Among the crimes that threaten national security, the Ukrainian legislator includes financing of actions committed for forcible change or overthrow of the constitutional order or seizure of state power, change of borders of the territory or state border of Ukraine; treason; encroachment on the life of a statesman or public figure; sabotage; espionage; obstruction of the lawful activities of the Armed Forces of Ukraine and other military formations, etc.

As for the Russian Federation, the legislator of the Russian Federation (Law 63-FZ, 1996) in Article 275 of the CC of 1996, pointing to the direct object of encroachment, uses succinctly stated: the security of the Russian Federation. Ryabchuk (2007) believes that the indication in the disposition of the article on the sovereignty and territorial integrity of the state is unnecessary because the external security of the state encompasses both of these concepts.

Also, without pointing to certain components of the object of the crime, for example, Article 175 of the CC of Kazakhstan (Law 226-V, 2014) in 2014 uses the most general concept of the object of encroachment - "National Interests of the Republic of Kazakhstan" or Art. 356 of the CC of the Republic of Belarus (Law 275-Z, 1999) in
1999 - "National Security of the Republic of Belarus" (Samedova, 2017).

It should be mentioned that the forms of treason are defined in the laws of most states in the postSoviet space. The position of the Georgian legislator stands out in this series. The current version of the CC of Georgia (Law 2287, 1999) provides for liability for certain forms of treason as separate types of crimes in particular articles. For example, in Art. 308 - for violation of the territorial integrity of Georgia, in Art. 312 - for encroachment on the defense capabilities of Georgia, in Art. 313 - for the issuance of state secrets, in Article 314 - for espionage, in Art. 319 - for providing assistance to a foreign state, foreign organization or organization controlled by a foreign state in hostile activities (Samedova, 2017).

Traditionally, the betrayal of the state occupies a small place in the general structure of the crime of the Republic of Azerbaijan. However, given that this act poses a serious threat to the external security of the state, the relevance of the study of criminal liability for treason in the historicallegal and comparative-legal aspects is beyond doubt.

As we can see, CaNS occupy a significant place in the criminal system of each state and their proper systematization reflects the place of protection of human rights and their priority.

\section{Conclusions}

The systematization of crimes is based on various indicators that contribute to the differentiation of crimes that threaten the internal and external security of states. Establishing precise criteria makes it possible to clearly distinguish crimes against national security among other types of crimes. The presence of a set of criteria provides an additional opportunity to divide crimes against national security into certain types: those that encroach on external and internal security It is considered necessary to group crimes against the foundations of national security into blocs, according to the areas of encroachment. Simultaneously, it should be emphasized that such a division is quite conditional and requires further rule-making work aimed at improving such a system of crimes.

Regarding further scientific research, it is necessary to study in more detail the positive international experience in combating the prevention of CaNS and to form a scientifically sound system of these measures. 


\section{Bibliographic references}

Afanasenko, S.I., \& Stoykov, I.M. (2015) CaNS, encroaching on political relations. South Ukrainian Law Journal, 1, 54-56. Recovered from

http://www.sulj.oduvs.od.ua/archive/2015/3/ 18.pdf

Aliyev, A.I., Rzayeva, G.A., \& Ibrahimova, A.N. (2020) Information Security: Legal Regulations in Azerbaijan and Abroad. Journal of Information Science. Recovered from

https://www.researchgate.net/publication/34 8047092_Information_security_Legal_regul ations_in_Azerbaijan_and_abroad

Anashkin, G.Z. (1964). Liability for treason and espionage. Moscow: Legal literature. Recovered from http://lawlibrary.ru/izdanie10431.html

Baranin, S. V. (2019). Synopsis of lectures on the subject "Criminal Law". Dnipro: Ministry of internal affairs of Ukraine. Recovered from https://dduvs.in.ua/wp-

content/uploads/files/Structure/library/stude nt/lectures/2020/kpk/12.pdf.

Chuvakov, O. (2017) Criminal-legal counteraction to CaNS of Ukraine: theory and practice. (doctoral thesis). National Academy of Sciences of Ukraine, Kyiv.

Gorbunova, L.V. (2016) Criminal liability for high treason and espionage in the criminal law of Austria and Liechtenstein. Mari Legal Bulletin, 1(16), 47-50.

Law 226-V, CC of the Republic of Kazakhstan, 2014. Recovered from https://online.zakon.kz/Document/?doc_id=3 1575252

Law 2287, CC of Georgia. Parliament of Georgia, 1999. Recovered from https://matsne.gov.ge/en/document/view/164 26? publication $=235$

Law 2341-III, Criminal Code of Ukraine. Verjovna Rada de Ucrania, Kyiv, 2001. Recovered from Recovered from https://zakon.rada.gov.ua/laws/show/234114\#Text

Law 2469-VIII, On National Security of Ukraine. Verkhovna Rada of Ukraine, Kyiv 2018. Recovered from Recovered from https://zakon.rada.gov.ua/laws/show/246919\#Text

Law 275-Z, CC of the Republic of Belarus. House of Representatives, 1999. Recovered from https://cislegislation.com/document.fwx ?rgn=1977

Law 302-IIQD, CC of the Republic of Azerbaijan. Adiloglu" Publishing House,
Baku, 1999. Recovered from http://base.spinform.ru/show_doc.fwx?rgn= 2670

Law 63-FZ. Criminal code of the Russian Federation, State Duma. Moscow, 1996. Recovered from http://www.consultant.ru/document/cons_do c_LAW_10699/

Mamedov, R.Y.O. (2016) Legal offenses against peace, human security, public safety under the criminal legislation of the Azerbaijan Republic. International Cooperation Of The Eurasian States: Politics, Economy, Law, 1, 89-95. Recovered from: https://cyberleninka.ru/article/n/yuridicheski e-sostavy-prestupleniy-protiv-mirabezopasnosti-chelovechestvaobschestvennoy-bezopasnosti-pougolovnomu

Marcella, G. (2013) The Transformation of Security In Latin America: A Cause for Common Action. Journal of International Affairs, 66(2), 67-82. Recovered from: https://www.jstor.org/stable/24388286

Pion-Berlin, D. (1989) Latin American National Security Doctrines: Hard and Softline Themes. Armed Forces \& Society, 15 (3), 411-429. Recovered from https://journals.sagepub.com/doi/10.1177/00 95327X8901500305

Ryabchuk, V.N. (2007). High treason and espionage: criminal law and criminological research. St. Petersburg: Legal Center Press. Recovered from https://www.twirpx.com/file/1725325/

Samandarova, F.Y. (Ed.). (2021). Commentary on the $\mathrm{CC}$ of the Republic. Baku: Legal Publishing House.

Samedova, Sh.T. (2017). Problems of criminal law: classification of crimes, differentiation of criminal liability and the construction of sanctions. Baku: Ekoprint. (In Russian)

Shatanska, T. (2017). CaNS, their qualifying features. Lawyer Shatarska Tamila Nazimivna. Recovered from https://www.shatarska.in.ua/11-zlochiniproti-osnov-nacionalno\%D1\%97-bezpeki$\%$ D1\%97x-kvalifikuyuchi-oznaki/

Vecherova, E.M. (2015). Some controversial issues of structuring a special part of the CC of Ukraine and prospects for its further improvement. Law and Society, 4(3), 178-183. Recovered from http://pravoisuspilstvo.org.ua/archive/2015/4 _2015/part_3/32.pdf 